\title{
PERSEPSI PENGEMUDI TERHADAP BANGUNAN PELENGKAP JALAN DI TOL CIPULARANG
}

\author{
Ni Luh Putu Shinta1, M.I. Dewi Linggasari' ${ }^{1}$, Hendy Limawan' ${ }^{1}$ dan Antonius ${ }^{1}$ \\ ${ }^{1}$ Program Studi Sarjana Teknik Sipil, Fakultas Teknik, Universitas Tarumanagara \\ Email: niluhs@ft.untar.ac.id \\ Email:dewi@ft.untar.ac.id \\ Email: hendylimawan@gmail.com \\ Email: anton93@rocketmail.com
}

\begin{abstract}
ABSTRAK
Jalan tol merupakan jalan yang dibangun khusus untuk mempersingkat jarak dan waktu tempuh dari satu tempat ke tempat lainnya dengan lalulintas yang padat. Salah satunya adalah Tol Cipularang telah digunakan sejak tahun 2005 dan dari tahun ke tahun jumlah kendaraan yang melalui Tol Cipularang terus bertambah. Dengan semakin ramainya kendaraan yang melalui Tol ini maka resiko terjadinya kecelakaan akan bertambah juga. Salah satu faktor yang perlu diperhatikan untuk mengurangi terjadinya kecelakaan tersebut adalah bangunan pelengkap jalan yaitu rambu lalu lintas , marka dan median jalan. Penelitian ini dilakukan dengan mendata persepsi pengemudi tentang rambu, marka jalan dan median jalan yang sekaligus sebagai bangunan peredam sialau yang ada di Tol Cipularang. Untuk Rambu dan Marka setelah mendata persepsi pengemudi maka dibandingkan dengan keadaan rambu dan marka jalan yang faktual ada di Tol Cipularang. Untuk Median jalan setelah kita mengetahui persepsi pengemudi terhadap bahan median yang paling aman untuk peredam silau, kenyamanan serta keindahan di jalan tol, maka pengolahan data persepsi pengemudi yang dalam bentuk kuisioner dilakukan dengan program SPSS. Hasil yang didapat dari penelitian ini adalah ketidaktersediaan rambu dan marka jalan tidak mempengaruhi pengemudi untuk mencapai tujuan dengan selamat dan pangemudi cenderung memilih bahan beton sebagai median sekaligus peredam silau.
\end{abstract}

Kata kunci: Tol Cipularang, rambu, marka dan median jalan, SPSS

\section{PENDAHULUAN}

Karena kenaikan jumlah kendaraan bermotor secara terus menerus maka menurut Peraturan Pemerintah RI Nomor 15 tahun 2005 Bab II tentang Penyelenggaraan Jalan Tol bertujuan meningkatkan efisiensi pelayanan jasa distribusi guna menunjang peningkatan pertumbuhan ekonomi terutama di wilayah yang sudah tinggi tingkat perkembangannya. Salah satu upaya pemerintah dalam mengurangi kemacetan serta untuk efisiensi dan efektivitas lalu lintas adalah dengan membangun jalan tol yang menghubungkan antar kota propinsi contohnya adalah Jakarta - Bandung yaitu Tol Cipularang. Keberadaan Tol Cipularang disamping untuk mengurai kemacetan lalulintas untuk kendaraan yang akan menuju ke Bandung dari Jakarta atau sebaliknya, juga harus diantisipasi meningkatnya jumlah kecelakaan yang diakibatkan. Kecelakaan lalu lintas merupakan salah satu penyebab kematian terbanyak di dunia. Jalan yang berkeselamatan saat ini merupakan isu global didunia yang menyangkut kondisi jalan, lalulintas, dan tingkat kecelakaan di negara berkembang termasuk Indonesia ( Sutandi C, 2014 ). Menurut data WHO (2013) tiap tahunnya ada 1,25 juta kematian yang di akibatkan oleh kecelakaan lalu lintas di dunia, lebih dari 90\% kematian tersebut terjadi di negara dengan pendapatan rendah dan menengah. Di Tol Cipularang juga masih sering sekali terjadi kecelakaan lalu lintas, terdapat beberapa blackspot yang memakan banyak korban. Perlu dilaksanakan proses pro aktif setiap saat untuk meningkatkan keselamatan berlalulintas dengan cara selalu memperhatikan dan mengidentifikasi potensi yang bisa meningkatkan keselamatan (Nishimura, 2017). Oleh karena itu kita harus sangat memperhatikan faktor keselamatan dan kenyamanan pengemudi kendaraan di Tol Cipularang. Salah satu hal penting yang harus diperhatikan adalah seberapa banyak petunjuk jalan yang disediakan melalui rambu dan marka jalan yang dapat dilihat dengan jelas oleh pengemudi 
kendaraan. Hasil studi sebelumnya tentang pengaruh pita penggaduh menunjukkan bahwa pita penggaduh tidak memberikan pengaruh signifikan terhadap penurunan angka kecelakaan di jalan Tol Cipularang (Meydita, 20012). Menurut Rudy Hermawan Karsaman (2007), jumlah rambu lalu lintas di jalan Tol Cipularang masih kurang, terutama rambu peringatan dan petunjuk yang berfungsi untuk mengarahkan dan menuntun arus lalu lintas dan juga spesifikasi teknis rambu dan marka juga masih kurang.

Marka jalan merupakan perlengkapan jalan yang ditempatkan menempel diatas badan jalan, sehingga marka dapat memandu pengemudi untuk berbelok, memutar balik juga ber hati-hati di area penyeberangan serta area padat pemukiman, dll ( Peraturan Menteri Perhubungan Republik Indonesia /PM No. 34 Tahun 2014 Tentang Marka Jalan ). Marka dibuat dari cat thermoplastik yang apabila terkena cahaya pada malam hari akan memantul, sehingga bersinar. Dengan demikian meskipun jalanan pada kondisi gelap marka jalan tetap akan dapat terlihat. Sedangkan rambu lalulintas adalah bagian perlengkapan jalan yang berupa lambang, huruf , angka, kalimat dan atau perpaduan yang berfungsi sebagai peringatan, larangan, perintah atau petunjuk bagi pengguna jalan yang dipasang di sepanjang jalan. ( Peraturan Menteri Perhubungan Republik Indonesia /PM No. 12 Tahun 2014 Tentang Rambu Lalulintas)

Selain Rambu dan Marka, faktor lainnya yang dapat menimbulkan kecelakaan lalu lintas adalah terganggunya (berkurangnya) jarak pandangan pengemudi akibat silau dari lampu kendaraan arah berlawanan pada malam hari (Ni Luh Shinta E.S, 2012). Karena pada malam hari kendaraan cenderung akan menyalakan lampu jauh kendaraan mereka dan jika berpapasan dengan kendaraan yang berlawanan arah akan menimbulkan silau bagi pengemudi. Dengan memasang pemisah jalan yang sekaligus berfungsi sebagai peredam silau akan memberikan keamanan, kenyamanan dan juga keindahan.

Berbagai jenis bangunan peredam cahaya dapat dibangun dengan menggunakan konstruksi berbahan beton, beton dengan enamel dan guardrail dengan tanaman. Menurut Peraturan Menteri Pekerjaan Umum No. 19 Tahun 2011 tentang Persyaratan dan Kriteria Perencanaan Teknis Jalan, penggunaan median dan pembatas jalan sangat penting untuk mengurangi terjadinya kecelakaan akibat silau dari kendaraan berlawanan dan agar kendaraan tidak masuk ke jalur yang berlawanan. Penelitian ini diharapkan dapat mengetahui bahan apa yang lebih baik untuk digunakan pada bangunan peredam silau di Tol Cipularang sesuai dengan persyaratan teknis dan persepsi pengemudi dan apakah jumlah rambu dan marka yang ada di sepanjang jalan sudah sesuai jumlah dan penempatannya dengan aturan yang berlaku.

\section{Identifikasi masalah}

Permasalahan yang melatar belakangi penelitian ini adalah seringnya terjadi kecelakaan lalulintas akibat fasilitas bangunan perlengkapan jalan seperti Rambu dan Marka, serta pembatas jalan di jalan tol yang sudah dibuat, tetapi masih kurang dapat berfungsi dengan baik karena jumlah dan ketinggiannya yang masih kurang. Masih banyak pengemudi yang mengalami kecelakaan karena terkena cahaya lampu kendaraan dari arah berlawanan yang dikarenakan ketinggian pembatas jalan masih kurang tinggi, sehingga membuat cahaya kendaraan dari arah berlawanan masih sangat mengganggu jarak pandangan pengemudi. Variasi bahan peredam silau seperti beton, beton dengan enamel serta guardrail dengan tanaman yang digunakan dapat menjadi median jalan yang juga dapat berfungsi sebagai peredam silau yang baik, Sehingga fungsi keselamatan dan keindahan juga dapat terpenuhi. 


\section{Tujuan penelitian}

Berdasarkan latar belakang, maka tujuan dari penelitian ini adalah menentukan efektifitas rambu,marka, dan median jalan pada kondisi jalan lurus, menurun, dan menanjak serta berbelok ke kiri, ke kanan dan lurus. Juga menentukan apakah ada perbedaan yang signifikan dari persepsi pengemudi terhadap rambu, marka dan jalan pada kondisi jalan tersebut. Beberapa permasalahan dapat dirumuskan sebagai berikut:

a. Bagaimana persepsi pengemudi terhadap bangunan perlengkapan jalan yang tersedia yaitu rambu dan marka?

b. Bagaimana persepsi pengemudi terhadap peredam silau sebagai faktor yang memenuhi keselamatan bagi pengguna jalan tol pada saat jalan lurus, menanjak dan menurun serta berbelok ke kiri, ke kanan dan lurus?

c. Bahan jenis apa yang dianggap paling aman oleh pengemudi sebagai median (bahan peredam silau)

\section{TINJAUAN PUSTAKA}

\section{Rambu}

Rambu lalu lintas jika dibagi berdasarkan fungsinya terdiri dari:rambu peringatan,rambu larangan,rambu perintah,rambu petunjuk,rambu peringatan.

Rambu peringatan digunakan untuk memberi peringatan kemungkinan ada bahaya di jalan atau tempat berbahaya pada jalan dan menginformasikan tentang sifat bahaya.

Penempatan rambu peringatan pada sisi jalan sebelum tempat berbahaya dilakukan dengan cara:

- paling sedikit 180 (seratus delapan puluh) meter, untuk jalan dengan kecepatan rencana lebih dari 100 (seratus) kilometer per jam;

- paling sedikit 100 (seratus) meter, untuk jalan dengan kecepatan rencana lebih dari 80 km per jam sampai dengan 100 (seratus) kilometer per jam;

- paling sedikit 80 (delapan puluh) meter, untuk jalan dengan kecepatan rencana lebih dari 60 (enam puluh) kilometer per jam sampai dengan 80 (delapan puluh) kilometer per jam; dan

- paling sedikit 50 (lima puluh) meter, untuk jalan dengan kecepatan rencana 60 (enam puluh) kilometer per jam atau kurang

Rambu dibedakan menjadi : rambu larangan, rambu perintah dan rambu petunjuk

\section{Marka jalan}

Marka Jalan adalah suatu tanda yang berada di permukaan jalan atau di atas permukaan jalan yang meliputi peralatan atau tanda yang membentuk garis membujur, garis melintang, garis serong, serta lambang yang berfungsi untuk mengarahkan arus lalu lintas dan membatasi daerah kepentingan lalu lintas

Marka dibedakan menjadi:

a. Marka membujur, adalah marka yang sejajar sumbu jalan

b. Marka melintang adalah marka jalan yang tegak lurus terhadap sumbu jalan

c. Marka serong adalah marka jalan yang membentuk garis utuh yang tidak termasuk dalam pengertian marka membujur atau marka melintang

d. Marka lambang adalah marka jalan berupa panah, gambar, segitiga, atau tulisan yang dipergunakan untuk mengulangi maksud rambu lalu lintas atau untuk memberitahu pengguna jalan yang tidak dapat dinyatakan dengan rambu lalu-lintas. 
e. Marka kotak kuning adalah marka jalan berbentuk segi empat berwarna kuning yang berfungsi melarang kendaraan berhenti di suatu area.

f. Marka lainnya, terdiri dari :marka tempat penyeberangan,marka larangan parkir atau berhenti di jalan,marka lajur sepeda, marka lajur khusus bus, marka lajur sepeda motor,marka jalan keluar masuk lokasi pariwisata,marka kewaspadaan dengan efek kejut,marka jalur evakuasi marka zona selamat sekolah, dan marka peringatan perlintasan sebidang antara rel dan jalan.

\section{Alinyemen vertical}

Alinyemen vertikal adalah perpotongan antara bidang vertikal dengan sumbu jalan (Banks, 2002). Desain alinyemen vertikal sangat mempengaruhi volume pekerjaan tanah yang akan dilakukan, sebab dengan melakukan desain tersebut dapat diperkirakan volume pekerjaan tanah yang harus dilaksanakan.

Alinyemen vertikal terdiri atas bagian lurus dan bagian lengkung. Ditinjau dari titik awal perencanaan, bagian lurus dapat berupa landai positif (tanjakan), atau landai negatif (turunan), atau landai nol (datar). Bagian lengkung vertikal dapat berupa lengkung cekung atau lengkung cembung.

\section{Alinyemen horizontal}

Alinyemen horizontal adalah garis proyeksi sumbu jalan tegak lurus bidang datar peta (trase) [Hadiwardoyo, 1995]. Trase jalan biasa disebut situasi jalan, secara umum menunjukan arah dari jalan yang bersangkutan. Alinyemen horisontal terdiri dari garis-garis lurus (tangent) yang dihubungkan dengan garis-garis lengkung (curve) [Sukirman,1999]. Garis-garis lengkung tersebut dapat terdiri dari lengkung lingkaran (circle/circular curve) ditambah dengan lengkung spiral (transition curve). Desain alinyemen horisontal sangat dipengaruhi oleh kecepatan rencana yang ditentukan berdasarkan tipe dan kelas jalan. Tikungan terdiri atas 3 bentuk umum yaitu :Full Circle, tikungan yang berbentuk busur lingkaran secara penuh;Spiral-circle-spiral (SCS) yaitu tikungan yang terdiri atas 1 lengkung circle dan 2 lengkung spiral;Spiral-spiral (SS) yaitu tikungan yang terdiri atas dua lengkung spiral.

\section{METODOLOGI PENELITIAN}

\section{Metode pengumpulan data}

Metode yang digunakan untuk pengumpulan data penelitian ini adalah pembagian kuisioner secara langsung kepada pengemudi pada rest area $\mathrm{km} 72$ arah Bandung dan rest area $\mathrm{km} 97$ arah Jakarta, dan juga secara online. Dalam pembagian kuisioner secara langsung di kedua rest area dilakukan juga wawancara selama responden mengisi kuisioner. Dan pengumpulan data faktual tentang rambu, marka dan median jalan di Tol Cipularang dengan pembuatan road inventory untuk mendapat data karakteristik jalan. Agar pelaksanaan penelitian efektif dan efisien, diperlukan metodologi penelitian yang sistimatis.

\section{Wawancara langsung dan online}

Metode survei wawancara langsung dengan menggunakan kuisioner dan metode kuisioner elektronik yang bertujuan untuk memperoleh perbedaan kualitas kegunaan dari berbagai variasi bahan peredam silau di ruas Tol Cipularang. Metode pengumpulan data yang dipergunakan adalah wawancara langsung dan on line. Peneliti memberikan pilihan kepada responden dengan pernyataan yang telah disediakan dan ditentukan oleh peneliti. Beberapa variabel yang digunakan dalam kuisioner yaitu tipe jalan lurus, tipe jalan menanjak, tipe jalan menurun, peredam silau berbahan beton, peredam silau berbahan beton dengan enamel, peredam silau berbahan guard rail (paddle) dengan tanaman, keindahan, pencahayaan, keamanan dan keselamatan. Metode ini digunakan karena bahan peredam silau yang digunakan di ruasTol Cipularang menggunakan 
berbagai bahan peredam silau untuk dinilai kegunaannya. Wawancara juga mencakup data umum respoden dan juga persepsinya terhadap marka dan penempatan rambu disepanjang jalan.

Beberapa variabel yang digunakan dalam kuisioner untuk rambu dan marka jalan yaitu tipe jalan lurus, tipe jalan menanjak dan menurun,untuk mengetahui jumlah rambu dan marka sepanjang jalan yang di lakukan penelitian, dan apakah sesuai dengan SPM dari Peraturan Menteri Perhubungan. Wawancara juga mencakup data umum respoden dan juga persepsinya terhadap marka dan penempatan rambu disepanjang jalan. Pengumpulan data yang dilakukan untuk mendapat informasi yang dibutuhkan untuk mencapai tujuan penelitian. Metode yang digunakan adalah dengan wawancara langsung. Wawancara langsung merupakan suatu teknik pengumpulan data dengan bertemu dan bertanya langsung kepada responden yang bersangkutan. Alat pengumpulan datanya berisi sejumlah pertanyaan yang harus dijawab oleh responden sesuai dengan persepsinya.

\section{Inventarisasi rambu, marka dan median jalan}

Untuk rambu, marka jalan dan ketinggian median sebagai bangunan peredam silau dilaksanakan dengan cara inventarisasi jalan pada sepanjang ruasnya dan menginventarisir setiap 50m panjang jalan. Hasil Road Inventory akan dipetakan dalam Strip Map yang memuat dari keberadaan dan fungsi marka, keberadaan dan fungsi rambu serta ketinggian bangunan peredam silau (Median).

\section{Metode analisis data}

Metode analisis data yang digunakan untuk penelitian ini adalah dengan cara uji sample $F$-test. Uji F dikenal dengan Uji serentak atau uji Model/Uji Anova, yaitu uji untuk melihat bagaimanakah pengaruh semua variable bebasnya secara bersama-sama terhadap variable terikatnya. Atau untuk menguji apakah model regresi yang kita buat baik/signifikan atau tidak baik/non signifikan. Uji $\mathrm{F}$ dapat dilakukan dengan membandingkan F hitung dengan Tabel F, jika F hitung >dari F tabel, (H0 di tolak H1diterima) maka model signifikansi atau bisa dilihat dalam kolom signifikan pada Anova (Olahan dengan SPSS, Gunakan Uji Regresi dengan Metode Enter/Full Model). Model signifikan selama kolom signifikansi $(\%)$ < Alpha (kesiapan berbuat salah tipe 1, yang menentukan peneliti sendiri, ilmu sosial biasanya paling besar alpha $10 \%$, atau $5 \%$ atau $1 \%$ ). Dan sebaliknya jika $\mathrm{F}$ hitung $<\mathrm{F}$ tabel, maka model tidak signifikan, hal ini juga ditandai nilai kolom signifikansi (\%) akan lebih besar dari alpha. Dalam penelitian komparasional yang melakukan pembandingan antar mean satu atau dua sampel, yaitu apakah memang secara signifikan mean satu atau dua sampel yang diperbandingkan atau dicari perbedaannya itu memang berbeda, ataukah perbedaan itu terjadi karena kebetulan saja (by change) dapat menggunakan Uji-F atau F-Test dan Chi Kuadrat (Chi Square). Uji-F atau F-Test adalah salah satu test statistik yang dipergunakan untuk menguji kebenaran atau kepalsuan hipotesis nol/nihil (Ho) yang menyatakan bahwa di antara dua buah mean sampel yang diambil secara random dari populasi yang sama tidak terdapat perbedaan yang signifikan.

Rumus umum yang digunakan dalam ANOVA

$\mathrm{H} 0: \mu 1=\mu 2=\mu 3=\ldots=\mu \mathrm{n}$, tidak ada perbedaan yang nyata antara rata - rata hitung dari $\mathrm{n}$ kelompok.

$\mathrm{H} 1: \mu 1 \neq \mu 2 \neq \mu 3 \neq \ldots \neq \mu$ n, ada perbedaan yang nyata antara rata - rata hitung dari $\mathrm{n}$ kelompok.

Anova merupakan salah satu dari berbagai jenis parametris yang sebelum digunakan harus melalui beberapa test yang dilakukan. Pengujian yang akan dilakukan adalah uji validitas dan reliabilitas lalu dilanjutkan dengan pengujian normalitas. Validitas dan reliabilitas menjadi bahasan utama 
dalam setiap pengukuran dalam penelitian. Keduanya berfokus bagaimana menciptakan pengukuran yang terhubung dengan konstruk yang diukur.

Reliabilitas digunakan sebagai indikator dalam mempercayai nilai dari suatu tes karena memiliki konsistensi (Jacobs, 1991).

Menurut Ety rochaety (2007), syarat minimum koefisien korelasi 0,6 karena dianggap memiliki titik aman dalam penentuan reliabilitas instrumen dan juga secara umum banyak digunakan dalam penelitian. Validitas digunakan sebagai pengembangan dan pengevaluasian suatu tes. Pada umumnya estimasi validitas berkisar 0,50 dapat dianggap memuaskan, sedangkan koefisien validitas kurang dari 0,30 biasanya dianggap tidak memuaskan. Di sisi lain, reliabilitas dinyatakan oleh koefisien reliabilitas (rxx') yang angkanya berada dalam rentang dari 0 sampai dengan 1,00, dimana koefisien reliabiltas semakin mendekati 1,00 maka semakin tinggi reliabilitasnya, begitu pun sebaliknya. Reliabilitas dapat dianggap memuaskan apabila koefisiennya minimal mencapai $\mathrm{rxx}^{\prime}=0,900$, namun terkadang suatu koefisien tidak mencapai nilai tersebut dan masih dianggap cukup berarti dalam suatu kasus tertentu terutama apabila skala yang bersangkutan digunakan bersama-sama dengan tes lain dalam suatu perangkat pengukuran (battery test) (Azwar, 2008).

\section{ANALISIS DAN PEMBAHASAN}

Hasil pengumpulan data karakteristik jalan, terdapat satu lokasi yang tidak sesuai dengan Peraturan Menteri No 13 Tahun 2004 (ditunjukkan pada bagian yang dilingkarkan hitam), yaitu tidak adanya rambu peringatan untuk memperingati pengemudi bahwa kondisi jalan tidak lagi mendatar melainkan menurun.

Hipotesis pada pengujian ini adalah:

H0 : persepsi pengemudi terhadap rambu dan marka pada ketiga kondisi geometrik jalan tidak berbeda secara signifikan

H1 : ada minimal 1 perbedaan persepsi pengemudi yang signifikan terhadap rambu dan marka pada ketiga kondisi geometrik jalan

Tabel 1. Hasil Tes Realibilitas untuk Ranbu dan Marka

\begin{tabular}{|l|c|c|}
\hline & Nilai Cronbach's Alpha & Jumlah Pertanyaan \\
\hline Rambu Pada Jalan Lurus & .778 & 4 \\
\hline Rambu Pada Jalan Menurun & .815 & 4 \\
\hline Rambu pada Jalan Menanjak & .726 & 4 \\
\hline Marka Pada Jalan Lurus & .811 & 4 \\
\hline Marka Pada Jalan Menurun & .733 & 4 \\
\hline Marka Pada Jalan Menanjak & .711 & 4 \\
\hline Median Lurus & .691 & 4 \\
\hline Median Menanjak & .684 & 4 \\
\hline Median Menurun & .688 & 4 \\
\hline
\end{tabular}

Tabel 2. Uji Kolmogorov-Smirnov

\begin{tabular}{|l|l|l|l|l|l|l|}
\hline \multicolumn{2}{|c|}{} & Rambu & Marka & \multicolumn{3}{c|}{ Median } \\
\hline $\mathrm{N}$ & Mean & 600 & 600 & 300 & 300 & 300 \\
\hline \multirow{3}{*}{ Parameter Normal } & 3.9300 & 3.9442 & 15.5200 & 15.3067 & 14.4500 \\
\cline { 2 - 7 } & Standar Deviasi & .63158 & .61544 & 2.81235 & 2.92137 & 2.86733 \\
\cline { 2 - 7 } & Absolut & .198 & .156 & .134 & .130 & 0.91 \\
\hline $\begin{array}{l}\text { Perbedaan } \\
\text { Terekstrem }\end{array}$ & Positif & .093 & .095 & .063 & .060 & 0,71 \\
\cline { 2 - 7 } & Negatif & -.198 & -.156 & -.134 & -.130 & -0.91 \\
\hline
\end{tabular}




\begin{tabular}{|l|l|l|l|l|l|l|}
\hline $\begin{array}{l}\text { Kolmogorov- } \\
\text { Smirnov Z }\end{array}$ & 4.846 & 3.826 & .134 & .130 & 0.91 \\
\hline $\begin{array}{l}\text { Signifikansi } \\
\text { Asimtotik }\end{array}$ & .000 & .000 & .000 & .000 & 0.000 \\
\hline
\end{tabular}

Hasil dari tes Kruskal-Wallis bisa dilihat pada tabel 3 dan tabel 4

Tabel 3. Peringkat Mean

\begin{tabular}{|l|c|c|c|c|}
\hline Jenis Jalan & $\mathrm{N}$ & $\begin{array}{c}\text { Peringkat Mean untuk } \\
\text { Rambu dan Marka }\end{array}$ & $\mathrm{N}$ & $\begin{array}{c}\text { Peringkat Mean Untuk } \\
\text { Median }\end{array}$ \\
\hline Lurus & 200 & 281.19 & 100 & 154.42 \\
\hline Menurun & 200 & 301.43 & 100 & 159.37 \\
\hline Menanjak & 200 & 318.88 & 100 & 137.72 \\
\hline Total & 600 & Total & 300 & 170.30 \\
\hline Lurus & 200 & 293.91 & 100 & 159.92 \\
\hline Menurun & 200 & 291.12 & 100 & 121.28 \\
\hline Menanjak & 200 & 316.47 & 100 & 153.50 \\
\hline Total & 600 & Total & 100 & 149.73 \\
\hline & & & 100 & 148.28 \\
\hline
\end{tabular}

Tabel 4. Hasil Uji Statistik

\begin{tabular}{|l|l|l|l|c|c|}
\hline & \multicolumn{1}{|c|}{ Rambu } & \multicolumn{3}{c|}{ Marka } & \multicolumn{3}{c|}{ Median } \\
\hline & & & Lurus & Menanjak & Menurun \\
\hline Chi Kuadrat & 4.872 & 2.631 & 3.489 & 17.979 & .196 \\
\hline df. & 2 & 2 & 2 & 2 & 2 \\
\hline Signifikansi Asimtotik & .088 & .268 & .177 & .000 & .000 \\
\hline
\end{tabular}

Dari hasil tes Kruskal-Wallis didapat nilai signifikansi asimtotik untuk rambu 0.088 dan untuk marka 0.268 , karena kedua nilai signifikansi asimtotiknya lebih besar dari 0.05 maka baik untuk rambu maupun untuk marka jalan didapat bahwa hipotesis H0 diterima dan H1 ditolak. H0 diterima berarti pada kondisi jalan lurus, menanjak, maupun menurun persepsi pengemudi terhadap pengaruh rambu dan marka tidak berbeda secara signifikan. Jadi pengemudi bisa menerima kondisi penempatan, informasi, dan visibilitas rambu dan marka dengan baik dan rambu dan marka dianggap bisa mengantarkan pengemudi ke tujuan dengan selamat. Walaupun pada kondisi faktualnya terdapat kekurangan rambu pada km99+800 arah Jakarta. Hal ini menandakan bahwa pengemudi tidak sepenuhnya memperhatikan keberadaan rambu atau marka jalan pada setiap kondisi jalan sehingga mereka tidak menyadari adanya kekurang rambu atau marka pada lokasi tertentu.

Dari hasil perhitungan dengan cara kruskall-wallis maka dapat disimpulkan bahwa pengemudi pada saat jalan lurus lebih memilih menggunakan beton dengan enamel sebagai median dengan angka 159,37 lebih banyak dibanding dengan beton sebanyak 154,42 dan guardrail dengan tanaman sebanyak 137,72 akan tetapi hasil dari persepsi pengemudi tersebut tidak banyak memberikan pengaruh karena perbedaannya tidak signifikan yang berarti pengemudi tidak terlalu menghiraukan, karena perbedaan tidak signifikan maka hipotesis H0 (Persepsi pengemudi terhadap ketiga variasi bahan peredam silau (populasi) tidak berbeda secara signifikan) diterima dan hipotesis H1 (Minimal 1 dari ketiga populasi tidak identik atau sama, persepsi pengemudi terhadap ketiga variasi bahan peredam silau memang berbeda secara signifikan) ditolak. 


\section{KESIMPULAN}

Adapun kesimpulan dari hasil analisis dalam penelitian ini yaitu:

1. Dari hasil perhitungan Kruskal-Wallis maka dapat disimpulkan bahwa persepsi pengemudi terhadap rambu yang ada di Tol Cipularang pada jalan lurus, menurun, dan menanjak hipotesis H0 diterima dan hipotesis H1 ditolak. Diterimanya H0 berarti tidak ada perbedaan yang signifikan pada persepsi pengemudi terhadap rambu dalam ketiga kondisi geometrik jalan tersebut. Jadi pengemudi menganggap bahwa bangunan pelengkap jalan rambu sudah mencukupi.

2. Dari hasil Kruskal-Wallis maka dapat disimpulkan bahwa persepsi pengemudi terhadap marka yang ada di Tol Cipularang pada jalan lurus, menurun, menanjak, hipotesis H0 diterima dan hipotesis $\mathrm{H} 1$ ditolak. Diterimanya hipotesis $\mathrm{H} 0$ berarti tidak ada perbedaan yang signifikan pada persepsi pengemudi terhadap marka dalam ketiga kondisi geometrik jalan tersebut. Jadi pengemudi menganggap bahwa bangunan pelengkap jalan marka sudah mencukupi.

3. Dari strip map yang dibuat berdasarkan kondisi faktual di Tol Cipularang dapat disimpulkan bahwa adanya kekurangan rambu peringatan pada km 99+800 untuk memperingati jalan yang menurun. Hal ini tidak sesuai dengan Peraturan Menteri No 13 Tahun 2004 Pasal 39 Ayat 2 tentang penempatan rambu peringatan yang mengharuskan rambu peringatan terpasang paling sedikit 80 meter untuk jalan dengan kecepatan rencana $60 \mathrm{~km} / \mathrm{jam}$ hingga $80 \mathrm{~km} / \mathrm{jam}$ dan paling sedikit 100 meter untuk jalan dengan kecepatan rencana 80 km/jam hingga 100 km/jam.

4. Perbandingan antara data strip map dan persepsi pengemudi menunjukkan bahwa walau ada lokasi yang kekurangan rambu peringatan, namun persepsi pengemudi tetap menunjukkan tingkat kepuasan yang baik. Jadi bisa disimpulkan bahwa ketidaktersediaan rambu tidak mempengaruhi pengemudi untuk mencapai tujuan. Hal ini terjadi karena ketidaktahuan atau kurangnya perhatian pengemudi dalam berkendara di Tol Cipularang.

5. Dengan cara kruskall-wallis maka dapat disimpulkan bahwa pengemudi pada saat jalan lurus lebih memilih menggunakan beton dengan enamel sebagai median, dibanding dengan beton dan guardrail dengan tanaman , akan tetapi hasil dari persepsi pengemudi tersebut tidak banyak memberikan pengaruh karena perbedaannya tidak signifikan yang berarti pengemudi tidak terlalu menghiraukan, karena perbedaan tidak signifikan maka hipotesis $\mathrm{H} 0$ diterima dan hipotesis H1 ditolak.

6. Dengan menggunakan metode yang sama pada saat jalan menanjak pengemudi lebih memilih menggunakan beton, dibanding beton dengan enamel dan guardrail dengan tanaman. Hasil dari persepsi pengemudi tersebut memberikan pengaruh karena perbedaannya yang signifikan berarti pengemudi memberikan respon sangat bagus menggunakan median beton saat jalan menanjak karena median beton sama sekali tidak tembus cahaya, karena perbedaan yang signifikan maka hipotesis $\mathrm{H} 0$ ditolak dan hipotesis $\mathrm{H} 1$ diterima.

7. Dengan metode yang sama, saat jalan menurun pengemudi lebih memilih menggunakan beton, lebih banyak dibanding beton+enamel dan guardrail+tanaman sebanyak akan tetapi hasil dari persepsi pengemudi tersebut tidak banyak memberikan pengaruh karena perbedaannya tidak signifikan yang berarti pengemudi tidak terlalu menghiraukan perbedaan median yang digunakan, karena perbedaan tidak signifikan maka hipotesis $\mathrm{H} 0$ diterima dan hipotesis $\mathrm{H} 1$ ditolak. 


\section{DAFTAR PUSTAKA}

Anwar Hidayat. Penjelasan dan Teori Uji Kruskal Wallis H. https://www.statistikian.com/2014/ 07/uji-kruskall-wallis-h.html. Diakses tanggal 15 November 2017

Azwar, S. (1997). Reliabilitas dan Validitas (Ed. 3).

Azwar, S. (2011). Tes Prestasi: Fungsi dan pengembangan pengukuran prestasi belajar. Yogyakarta: Pustaka Pelajar.

BANKS,J.h. 2002. Introduction to Transportation Engineering 2nd ed., New York: McGraw - Hill Departemen Pekerjaan Umum Direktorat Jenderal Bina Marga, Standar Konstruksi dan Bangunan, Tentang Geometri Jalan Bebas Hambatan Untuk Jalan Tol, No. 007/BM/2009

Direktorat Jenderal Bina Marga. 1992. Standar Perencanaan Geometrik untuk Jalan Perkotaan. Jakarta.

Ghozali, Imam. 2013. Aplikasi Analisis Multivariate dengan Program SPSS. Edisi Ketujuh. Semarang: Badan Penerbit Universitas Diponegoro

Indra Jaya. Alinyemen Vertikal.https://www.academia.edu/28910302/Alinyemen_Vertikal. Diakses tanggal 29 september 2017.

Jacobs, L. C. (1991). Test Reliability. IU Bloomington evaluation service \&testing. Diakses pada tanggal 7 November 2017 dari www.indiana.edu.

Lampiran Peraturan Menteri Pekerjaan Umum. (2012). "Nomor 05/PRT/M/2012 Tentang Pedoman Penanaman Pohon Pada Sistem Jaringan Jalan”. Jakarta.

Lawrence L. Lapin. (1983). “Probability and Statistics for Modern Engineering”. United States of America: San Josẻ State Unversity.

Karsaman, Rudy Hermawan.2007."Audit Keselamatan Jalan Tol di Indonesia” dalam jurnal Teknik Sipil. Vol. 14 No. 3, September 2007.PT.Prenhallindo.

Menteri Perhubungan Republik Indonesia. 2014. Peraturan Menteri Perhubungan Republik Indonesia No PM 13 Tahun 2014 tentang Rambu Lalu Lintas, Jakarta: Menteri Perhubungan Republik Indonesia.

Menteri Perhubungan Republik Indonesia. 2014. Peraturan Menteri Perhubungan Republik Indonesia No PM 34 Tahun 2014 tentang Marka Jalan. Jakarta: Menteri Perhubungan Republik Indonesia. Anastasi, A., \& Urbina, S. (1998). Tes Psikologi (Edisi Terjemahan). Jakarta.

Neuman, W. L. (2007). Basic of social research: Qualitative and quantitative approaches, second edition. Pearson Education, Inc.

Nishimura, Masahiro. 2017. " Application of Road Safety Audits in Japan Organizational Culture and Absorptive Capacity Perspective", Jurnal of Safety Studies. Macrothink Institute.

Peraturan Menteri Pekerjaan Umum. (2011). "Nomor 19/PRT/M/2011 Tentang Persyaratan Teknis Jalan Dan Kriteria Perencanaan Teknis Jalan”. Jakarta: Berita Negara Republik Indonesia Tahun 2011 Nomor 900.

Peraturan Pemerintah Republik Indonesia. (2005). "Nomor 15 Tentang Jalan Tol”. Jakarta: Lembaran Negara Republik Indonesia Tahun 2005 Nomor 32.

Peraturan Kementrian Perhubungan Republik Indonesia . (2014), PM No. 12 Tentang Rambu Lalu lintas.

Peraturan Kementrian Perhubungan Republik Indonesia . (2014), PM No. 34 Tentang Marka Jalan Rochaety E. (2007). Metodologi Penelitian Bisnis: Dengan Aplikasi SPSS, Edisi Pertama. Penerbit Mitra Wacana Media: Jakarta.

Shinta E.S., Ni Luh. (2012). "Pengaruh Rancangan Peredam Silau Terhadap Jarak Pandang (Studi Kasus Tol Cipularang)". Jakarta.

Sugiyono. (2010). Metode penelitian pendidikan: Pendekatan kuantitatif, kualitatif, dan R\&D. Bandung: Alfabeta. 
Sutandi A.C., (2014). " Integrated Road Safety Approach Towards Safer Road In Indonesia, dalam Jurnal Transportasi Vol. 14 No. 2 Agustus 2014. 